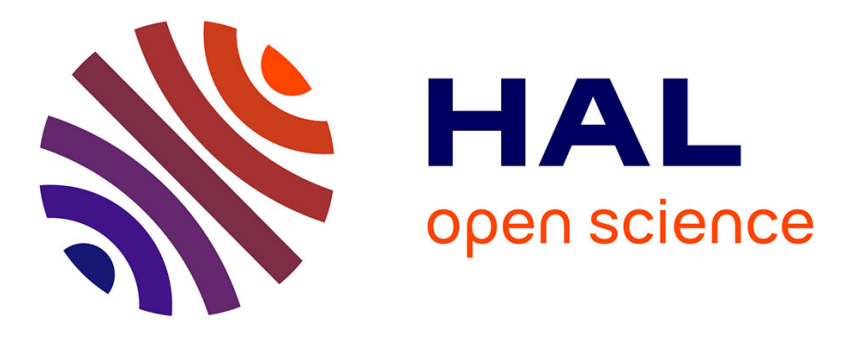

\title{
Duodenal tumor risk in Lynch syndrome
}

\author{
Nassim Hammoudi, Marion Dhooge, Romain Coriat, Sarah Leblanc, \\ Maximilien Barret, Benoit Bordacahar, Frederic Beuvon, Frederic Prat, Fanny \\ Maksimovic, Stanislas Chaussade
}

\section{- To cite this version:}

Nassim Hammoudi, Marion Dhooge, Romain Coriat, Sarah Leblanc, Maximilien Barret, et al.. Duodenal tumor risk in Lynch syndrome. Digestive and Liver Disease, 2019, 51, pp.299 - 303. 10.1016/j.dld.2018.10.005 . hal-03486353

\section{HAL Id: hal-03486353 https://hal.science/hal-03486353}

Submitted on 20 Dec 2021

HAL is a multi-disciplinary open access archive for the deposit and dissemination of scientific research documents, whether they are published or not. The documents may come from teaching and research institutions in France or abroad, or from public or private research centers.
L'archive ouverte pluridisciplinaire $\mathbf{H A L}$, est destinée au dépôt et à la diffusion de documents scientifiques de niveau recherche, publiés ou non, émanant des établissements d'enseignement et de recherche français ou étrangers, des laboratoires publics ou privés.

\section{(ㄷ)(1) $\$$}

Distributed under a Creative Commons Attribution - NonCommerciall 4.0 International 


\section{DUODENAL TUMOR RISK IN LYNCH SYNDROME}

Authors: Nassim HAMMOUDI, MD (1) , Marion DHOOGE, MD (1), Romain CORIAT, MD, PhD (1,2), Sarah LEBLANC, MD, MSc (1), Maximilien BARRET, MD, PhD (1,2), Benoit BORDACAHAR, MD, MSc (1), Frederic BEUVON, MD, PhD (3), Frederic PRAT, MD, PhD $(1,2)$, Fanny MAKSIMOVIC (1), Stanislas CHAUSSADE , MD, $\operatorname{PhD}(1,2)$

\section{Affiliations :}

(1) Gastroenterology Unit, Cochin University Hospital, Université Paris Descartes, Paris, France

(2) Unité INSERM U1016, Université Paris Descartes, Sorbonne Paris Cité, Paris, France

(3) Digestive Pathology Unit, Cochin University Hospital, Université Paris Descartes, Paris, France

Word count: 2645

Abstract: 210 Manuscript: 2435

Pages: 17 Figures and tables: 5

References: 28

Conflict of interest: All authors have no conflict of interest to declare

Corresponding Author: Marion DHOOGE

E-mail: marion.dhooge@aphp.fr

27, rue du Faubourg Saint-Jacques 75014 Paris 


\section{Abstract}

\section{Background and Aims:}

Lynch syndrome (LS) is associated with an increased risk of small bowel tumors but routine screening is not recommended in international guidelines. The aim of our study was to determinate the prevalence of duodenal tumors in a French cohort of LS patients.

\section{Methods:}

Patients carrying a germline pathogenic variant in a MMR gene, supported by our local network, in which at least one upper endoscopy had been performed, were included. We registered the occurrence of duodenal lesions in those patients.

\section{Results:}

154 LS patients were identified including respectively 85 MSH2 and 41 MLH1 mutated patients respectively. Seven out of 154 (4.5\%) had at least one duodenal lesion. Median age at diagnosis was 58 years (range: 49-73). The twelve lesions locations were: descending duodenum $(n=7)$, genu inferius $(n=2)$, duodenal bulb $(n=1)$, ampulla $(n=1)$, fourth duodenum $(n=1)$. Three lesions were invasive adenocarcinomas. The incidence rate of duodenal lesions in patients with $M S H 2$ or $M L H 1$ pathogenic variants was respectively $7.1 \%$ ( 6 out of 85 ) and $2.4 \%$ ( 1 out of 41 ) emphasizing a trend towards increased risk of developing duodenal lesion in MSH2 mutated patients: OR: 5.17, IC95\% (0.8-60.07), $p=0.1307$.

\section{Conclusion:}

Regarding this high prevalence rate, especially in $M S H 2$ patients, regular duodenal screening during upper endoscopy should be considered in routine in LS patients. 


\section{Introduction}

Lynch syndrome (LS), is an autosomal dominant condition first described in $1966^{1}$. It is caused by germline pathogenic variants in one of the four DNA mismatch-repair (MMR) genes: MLH1, MSH2, PMS2 or MSH6 or by deletions in the EPCAM gene (MSH2 promoter) ${ }^{2}$. Nearly $90 \%$ are located in $M L H 1$ and $M S H 2$ and approximately $10 \%$ in MSH6 and $P M S 2^{3}$.

LS is associated with an increased risk of developing gastrointestinal, gynecological and other types of cancers ${ }^{4,5}$. Among these, colorectal cancer is the one with the highest risk of occurrence. LS is accounting for about 3\% of newly diagnosed cases of colorectal malignancy $6,7,8$.

Small bowel adenocarcinomas (SBA) are rare tumors ${ }^{9}$. An increased risk of SBA has been reported in patients with MMR pathogenic variants. The lifetime risk for this cancer varies a lot depending on the studies ranging from $0.6 \%$ to $12.0 \% 10,11,12$ which corresponds to a more than 100 fold incidence increased compared to sporadic ones ${ }^{13}$. In SBA, the duodenum is the most frequently involved segment with 50 to $80 \%$ of cases followed by the jejunum (10-25\%) and finally ileum (5-15\%) ${ }^{14,15}$. In LS-associated SBA, these location data appear to be similar ${ }^{16}$. Therefore, based on these epidemiologic data, the majority of SBA can be diagnosed during conventional endoscopic examination such as esophagogastroduodenoscopy (EGD) and colonoscopy with ileal intubation.

However, based on several publications suggesting that routine surveillance of the small bowel in LS was not cost-efficient ${ }^{17,18}$, both American and European recommendations, which agree on the realization of an initial EGD with Helicobacter pylori biopsies at age 30-35, do not include systematic screening surveillance of the small bowel in their guidelines. Some recent publications suggest that endoscopic investigations such as 
small bowel capsule (VCE) might have an interest in this indication ${ }^{19,20}$ leading Giardello and al, to consider the realization of capsule endoscopic screening at 2-3 years intervals beginning at age $30-35$.

Carriers of different MMR genes pathological variants exhibit distinct patterns of cancer risk $^{21}$. In the ERISCAM study, Bonadona and al reported differences in tumor incidences depending on the DNA MMR genes involved in the LS pathogeny: 69 small bowel tumors were reported with respectively 37 affecting patients with a MLH1 variant $(n=814$, 4,5\%), 29 for MSH2 (n=697, 4.2\%) and 3 for MSH6 (n=71, 4\%). Interestingly, Moller et al (21) reported a 3-fold increased cumulative incidence risk at 75 years old for MLH1 patients.

According to these data and in regard with the low morbidity of upper endoscopy we aimed to determinate in this study the prevalence of duodenal lesions in a French cohort of patients with LS and to describe this condition, in order to precise surveillance recommendations in this population. 


\section{Patients and Methods}

\section{Patient selection and eligibility:}

Since 2013, French national cancer institute (INCa) finances local network to coordinate the management of patients genetically predisposed to neoplastic lesions. The « Reseau PRED-IdF » is one of this healthcare networks, coordinating the management of patients predisposed to digestive cancers, including those with LS, in Paris area. Adult patients with an identified germline pathogenic variant in an MMR gene, supported by the local Cochin University Hospital PRED-IdF network, were eligible for data collection, if they had at least one diagnostic EGD performed.

EGDs were performed every 3 to 4 years, in the occasion of a colonoscopy, according to our PRED-IdF guidelines. We used either standard gastroscopes or pediatric colonoscopes according to the choice of the gastroenterologist performing the exam.

Chromoendoscopy with indigo carmine or virtual chromoendoscopy as Narrow Band Imaging or Blue Laser Imaging was not systematically performed.

The occurrence of a duodenal lesion might be diagnosed before or after the LS genetic confirmation but had to be recorded in the patient's medical file.

A written informed consent was obtained from all patients for participation into this trial.

\section{Data collection:}

Data on patient's characteristic (age, sex, smoking, body-mass-index), MMR gene involved, type of duodenal lesion (location, age at diagnosis, histological features 
including immunohistochemistry, therapeutic intervention), familial history of small bowel tumor and follow-up were collected retrospectively.

All data sheets were reviewed by the same author (MD) in order to make a uniform interpretation of retrospective data.

\section{Molecular data:}

All LS patients had a class 4 or 5 pathogenic variant in one of the four MMR genes or EPCAM, identified by gene sequencing in index case or targeted analysis in the previously identified LS families

\section{Pathological examination}

All patients with duodenal tumor underwent immunohistochemistry of the MMR proteins in at least one of the lesion using respectively: MLH1 (G168-728, Pharmingen®), MSH2 (FE11, Zymed®), MSH6 (44, Clinisciences®), PMS2 (A16-4, Pharmingen $®$ ).

\section{Stastistics}

Number of duodenal lesions in patients with either $M S H 2$ or other DNA mismatch repair gene pathogenic variant was assessed. Comparison between the two incidence rates was tested using a two-tailed Fisher's exact test. Statistical significance was reached if $\mathrm{p} \leq$ 0,05 . 


\section{Results}

\section{Study population characteristics:}

One hundred and fifty-four patients with LS were included in our study. 85 patients had a MSH2 pathogenic variant (55.2\%), 41 a $M L H 1$ pathogenic variant (26.6\%), 26 a $M S H 6$ pathogenic variant (16.9\%), 1 an EPCAM pathogenic variant $(0,6 \%)$ and 1 a double pathogenic variant in both $M L H 1$ and $M S H 2$ genes $(0.6 \%)$. No patients diagnosed with a PMS2 pathogenic variant were included in Cochin's PRED-IdF network at the time of this study.

\section{General Characteristics of patients with duodenal lesions:}

Twelve duodenal lesions were diagnosed in 7 of our patients (Overall incidence: $4.5 \%$ ). General characteristics of these 7 patients are reported in Table 1 . The median age at diagnosis was 58 years (range: 49-73). Six out 7 patients were male (85.7\%). Three patients were overweighed (42.9\%) and one presented with obesity $(14.3 \%)$. The calculated mean BMI was 26.6 (range: 23.3-30.1). One patient of our cohort was a smoker (14.3\%).

Three patients (42.9\%) had a personal past history of colon cancer and 1 of gastric adenocarcinoma. This patient had also been treated for 3 successive urothelial carcinomas. Two patients had a Muir-Torre syndrome with a personal history of keratoacanthomas and sebaceous cutaneous lesions

Three patients developed cancers not originally considered of LS spectrum: two prostatic adenocarcinomas and one a sarcomatoid carcinoma of the adrenal gland.

Two patients from this cohort were first degree related, carrying the same MSH2 pathogenic variant. None of the five other patients had a family history of duodenal lesion. 
Six out of our 7 patients (85.7\%) with duodenal lesions had a MSH2 pathogenic variant. Only one patient had a MLH1 (14.3\%) pathogenic variant. No patient with MSH6 or EPCAM pathogenic variant displayed any duodenal lesion.

Overall, the incidence rate of duodenal lesions in LS patients with MSH2 or MLH1 was respectively $7.1 \%$ ( 6 out of 85 ) and $2.4 \%$ (1out of 41 ). These data emphasized a trend toward an increased risk of developing duodenal lesion when carrying a MSH2 pathogenic variant compared to other LS genetic instabilities without reaching statistical significance: OR: 5.17, IC 95\% [0.8 - 60.07], p=0.1307.

\section{Duodenal lesions characteristics}

Twelve duodenal tumors were diagnosed in our 7 patients. Characteristics of these lesions are reported in Table 2.

In these 12 tumors there were 3 invasive adenocarcinomas (25\%), 1 intra-mucosal adenocarcinoma (8.3\%), 6 adenomas in high-grade dysplasia (50\%) and 2 adenomas in low-grade dysplasia (16.7\%). No patient had metastatic disease.

The 4 adenocarcinomas were found in patients carrying an MSH2 pathogenic variant. These findings underlined a trend toward an increased risk of developing duodenal adenocarcinomas in this subgroup of patients although without reaching statistical significance: OR 7.68, IC 95\% [0.4-145.2], $\mathrm{p}=0.1282$.

Lesions were located as follow: $7(58.3 \%)$ in the second duodenum, 2 in the genu inferius (16.7\%), 1 next to the Vater ampulla, 1 in the duodenal bulb and 1 in the fourth duodenum $(8.3 \%)$.

All lesions were resected in a curative intention. The 3 invasive adenocarcinomas were treated surgically with lymph node dissection, 2 by cephalic duodenopancreatectomy and 1 by resection of the $3^{\text {rd }}$ and $4^{\text {th }}$ duodenum, with no major postoperative complications. Adjuvant chemotherapy (FOLFOX regimen) was prescribed to these 
three patients due to lymph node invasion or a T4 tumoral stage according to the TNM classification in the pathological examination.

The 8 other lesions were treated endoscopically with endoscopic mucosal resection (EMR), 2 of which were piecemeal resection due to the size of the tumor. No post procedure complications were recorded including hemorrhage or perforation.

Immunohistochemistry of the MMR proteins was available for 8 among 12 lesions. At least one duodenal lesion in each patient underwent somatic screening. Immunohistochemistry showed loss of MSH2 and MSH6 proteins signal in the duodenal lesions of the 6 patients with a germline MSH2 pathogenic variant. There was a loss of MLH1 and PMS2 proteins signal in the duodenal adenoma in high-grade dysplasia of the patient with a germline $M L H 1$ pathogenic variant.

\section{Follow-up:}

Mean follow-up time from diagnosis of the first duodenal lesion to the last multidisciplinary meeting for each patient was 4.2 years (range: $0.6-12.8$ ).

Four patients underwent a complete small bowel examination during the follow-up period: 3 by videocapsule and 1 by Magnetic Resonance Enterography. Among them, 1 had a jejunal adenoma in high-grade dysplasia. This lesion was treated surgically because of its non-accessibility by endoscopic route. The 3 other patients presented no other small bowel lesion.

No patient was lost to follow-up during the study period and none of our 7 with duodenal lesion died of any cause. 


\section{Discussion}

We there report, to the best of our knowledge, the first study evaluating the incidence of duodenal lesions by systematic EGD in patients with LS. Our data suggest a nonnegligible risk of duodenal tumors, especially in patients with $M S H 2$ pathogenic variants, and highlights the need to redefine our management strategy in LS patients concerning small bowel lesions risk in order to diagnose and treat such lesions.

As reported in previous studies, 50 to $80 \%$ of small bowel lesions are found in the duodenum in sporadic neoplasias as in LS patients. The recent study published by Haanstra and al has even found lesions only in the duodenum. Their study evaluated prospectively the prevalence of small-bowel neoplasia in asymptomatic patients with LS by VCE and found a 1.5\% rate in a cohort of 200 patients $^{22}$. All neoplastic lesions were located in the duodenum. The relative low prevalence rate found in this study is to be compared to the higher (albeit highly variable) rate in other epidemiological studies described above ( 0.6 to $12 \%$ ). VCE, although being a minimally invasive procedure, might miss duodenal lesions ${ }^{23},{ }^{24}$ and a 100 fold increased incidence of small bowel neoplastic lesions has already been reported in LS patients.

The importance of early diagnosis of duodenal lesions, which can occur very early in these patients ${ }^{25}$, in order to treat them and prevent its spread is a major challenge.

Conventional upper digestive tract endoscopy is a minimally invasive procedure that can be performed during the same general anesthesia that the screening colonoscopy regularly accomplished in these patients. The cost and the duration of the procedure performed are in these cases only slightly increased.

Despite not being part of the international recommendations, the regular realization of an upper digestive tract endoscopy concomitantly with a screening colonoscopy is 
already part of the "Reseau PRED-IdF" guidelines regarding the minimally invasive nature of the procedure.

In our cohort, 4 out of the 12 (33\%) duodenal lesions were located in the genu inferius or in the fourth duodenum out of access of a conventional upper endoscopy (Figure3). The use of a pediatric colonoscope frequently allows the visualization of the entire duodenal frame without increasing the morbidity of the procedure. Using a pediatric colonoscope to perform the upper digestive tract exploration might be useful in LS patients.

Furthermore, flat adenomas were found in patients of the cohort. Chromoendoscopy, using intravital staining of the duodenal mucosa with indigo carmine, could increase the detection rate of such lesions ${ }^{26}$ and might also be helpful in this indication.

Differences in the tumor incidence rates considering the pattern of MMR gene pathogenic variant in patients with LS are reported. These differences are also described concerning small bowel lesions. In our cohort, the incidence of neoplastic duodenal lesions was higher in $M S H 2$ patients (7.1\%) when compared with $M L H 1$ (2.4\%) or other LS patients (0\%). Moreover, these differences were also found in small bowel adenocarcinomas incidence rates in our cohort and those invasive lesions were exclusively found in patients with a MSH2 pathogenic variant. Conflicting epidemiological data have been recently published in the literature ${ }^{11,12,21}$. If $M S H 6$ seems to be the pathogenic variant associated with the less incident tumors overall in all the studies including ours, the difference in terms of small bowel lesions incidence (higher in MSH2 patients) was also found in the Bonadona et al epidemiological work. In contrast to data recently published on the subject, we decided to consider all small bowel lesions and not only adenocarcinomas, which may have led to the distinct results with the Moller et al study. 
Interestingly, we found that two of the patients diagnosed with a small bowel adenocarcinomas had been treated in their past medical history for prostatic cancer. Recent publications showed that patients with hypermutated prostate cancers often have mismatch repair gene mutations frequently affecting $M S H 2^{27,28}$. Question may arise whether additional genetic factors could explain this occurrence in these two patients with MSH2 pathogenic variants, and larger epidemiological studies are needed to answer this question.

Our study however presents limitations. First of all the small number of patients in our cohort, the monocentric and retrospective characters of the study does not permit us to generalize our data.

Moreover, the fact that the Cochin University Hospital is a tertiary endoscopic and digestive oncology center could have caused a selection bias with the recruitment of patients referred to our institution because of this specialization. However, because of the scarcity of the pathology discussed, this bias could difficultly be avoided.

Despite these potential bias, considering our data and experience on the topic, the relatively high incidence of duodenal lesions in LS patients (especially in MSH2), their frequently asymptomatic features, and the minimally invasive nature of an upper digestive tract endoscopy, performed during a general anesthesia for screening colonoscopy, we truly believe that adding this examination (potentially using a pediatric colonoscope to reach the fourth duodenum) to our practice could benefit to our patients, especially in the high risk patients such as those with $M S H 2$ and $M L H 1$ pathogenic variants.

These features and the time between two screening upper endoscopies cannot result in immediate large international recommendations. However, our findings underline the 
crucial need for future larger collaborative nationwide studies involving healthcare networks specialized in Lynch Syndrome management to precise this issue. 


\section{Bibliography}

1 Lynch HT. Hereditary factors in cancer. Study of two large midwestern kindreds. Arch Intern Med. 1966

L Ligtenberg MJ, Kuiper RP, Leung Chan T, et al. Heritable somatic methylation and inactivation of MSH2 in families with Lynch syndrome due to deletion of the 3ф exons of TACSTD1. Nat. Gen 2009

Lynch HT, De La Chapelle A. Hereditary Colorectal Cancer. N Engl J Med. 2003;34810.

Vasen HFA, Blanco I, Aktan-Collan K, et al. Revised guidelines for the clinical management of Lynch syndrome (HNPCC): recommendations by a group of European experts. Gut 2013

Giardiello FM, Allen JI, Axilbund JE, et al. Guidelines on Genetic Evaluation and Management of Lynch Syndrome: A Consensus Statement by the US Multi-Society Task Force on Colorectal Cancer. Am J Gastroenterol. 2014

Aaltonen LA, Salovaara R, Kristo P, et al. Incidence of Hereditary Nonpolyposis Colorectal Cancer and the Feasibility of Molecular Screening for the Disease. N Engl J Med. 1998

Salovaara R, Loukola A, Kristo P, et al. Population-based molecular detection of hereditary nonpolyposis colorectal cancer. J Clin Oncol. 2000 variants in DNA Mismatch-Repair Genes in Colon Cancer. N Engl J Med. 2006

Aparicio T, Zaanan A, Svrcek M, et al. Small bowel adenocarcinoma: Epidemiology, risk factors, diagnosis and treatment. Dig Liver Dis. 2014 
Bonadona V, Bonaïti B, Olschwang S, et al. Cancer risks associated with germline pathogenic variants in MLH1, MSH2, and MSH6 genes in Lynch syndrome. JAMA. 2011

Engel C, Loeffler M, Steinke V, et al. Risks of Less Common Cancers in Proven Pathogenic variant Carriers With Lynch Syndrome. J Clin Oncol. 2012

Aarnio M, Mecklin J-P, Aaltonen LAet al. Life-time risk of different cancers in hereditary non-polyposis colorectal cancer (hnpcc) syndrome. Int J Cancer. 1995

Lepage C, Bouvier A-M, Manfredi S, et al. Incidence and Management of Primary Malignant Small Bowel Cancers: A Well-defined French Population Study. Am J Gastroenterol. 2006

Schulmann K, Brasch FE, Kunstmann E, et al. HNPCC-associated small bowel cancer: Clinical and molecular characteristics. Gastroenterology. 2005

ten Kate GL, Kleibeuker JH, Nagengast FM, et al. Is surveillance of the small bowel indicated for Lynch syndrome families? Gut. 2007

Watson P, Vasen HFA, Mecklin J-P, et al. The risk of extra-colonic, extra-endometrial cancer in the Lynch syndrome. Int J Cancer. 2008

Koornstra JJ, Kleibeuker JH, Vasen HF. Small-bowel cancer in Lynch syndrome: is it time for surveillance? Lancet Oncol. 2008

Saurin J-C, Pilleul F, Soussan E, et al. Small-bowel capsule endoscopy diagnoses early and advanced neoplasms in asymptomatic patients with Lynch syndrome. Endoscopy. 2010 gender up to 75 years of age: a report from the Prospective Lynch Syndrome Database. Gut. 2018. 
Haanstra JF, Al-Toma A, Dekker E, et al. Prevalence of small-bowel neoplasia in Lynch syndrome assessed by video capsule endoscopy. Gut. 2015

Baichi MM, Arifuddin RM, Mantry PS. Small-bowel masses found and missed on capsule endoscopy for obscure bleeding. Scand J Gastroenterol. 2007

Chong AKH, Chin BWK, Meredith CG. Clinically significant small-bowel pathology identified by double-balloon enteroscopy but missed by capsule endoscopy. Gastrointest Endosc. 2006

Rodriguez-Bigas MA, Vasen HF, Lynch HT, et al. Characteristics of small bowel carcinoma in hereditary nonpolyposis colorectal carcinoma. International Collaborative Group on HNPCC. Cancer. 1998 in the Evaluation of Duodenal Abnormalities: a Prospective, Randomized Comparison. Endoscopy. 2003

27 Pritchard CC, Morrissey C, Kumar A, et al. Complex MSH2 and MSH6 mutations in hypermutated microsatellite unstable advanced prostate cancer. Nat Commun. 2014 Res. 2017. 


\section{Tables and figures' legends}

TABLE 1: General Characteristics of patients with duodenal lesions

TABLE 2: Characteristics of duodenal lesions

Abbreviations: LGD = Low-grade dysplasia; HGD = High-grade dysplasia; ADK = Adenocarcinoma

* Performed in at least one lesion per patient

FIGURE 1: Patient 1: Adenoma in high-grade dysplasia of the second duodenum (1a : white light ; $1 \mathrm{~b}$ : with magnification by BLI FUJIFILM®)

FIGURE 2: Patient 4: Loss of expression of MSH2 protein in immunohistochemistry

FIGURE 3: Repartition of all duodenal lesions diagnosed in the 7 patients 


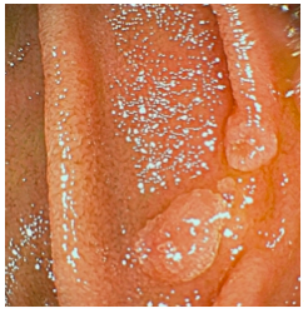

Y.

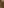

$\left.\left.-4 \cos ^{2}\right)^{2}\right)^{2}$

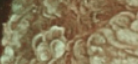

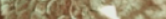

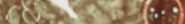

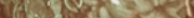

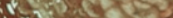

(8)

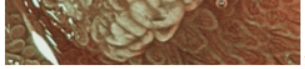


HES coloration, X 20

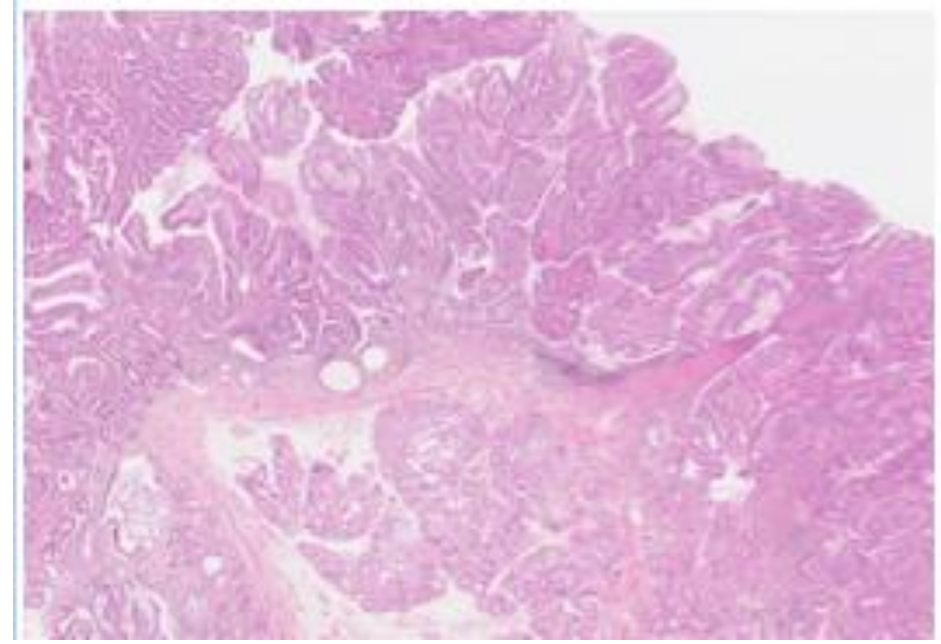

MSH2 Antibody, X 200

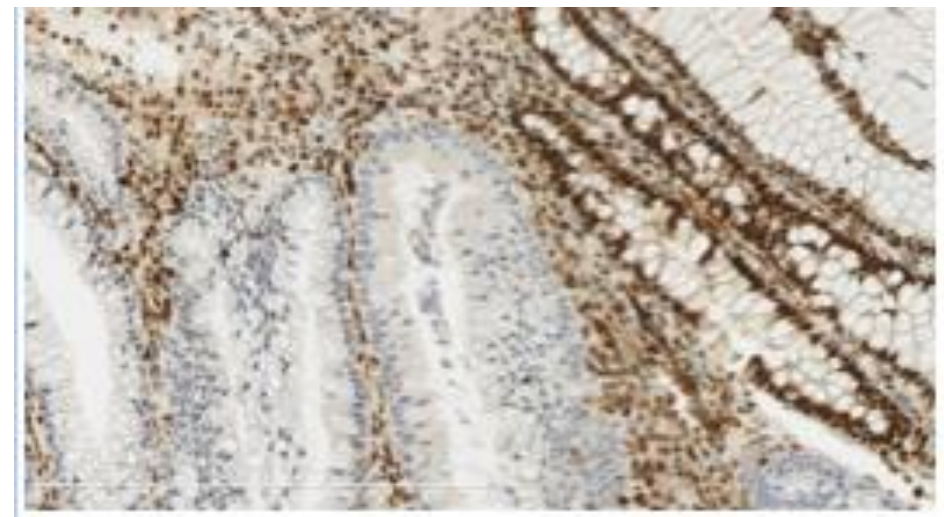




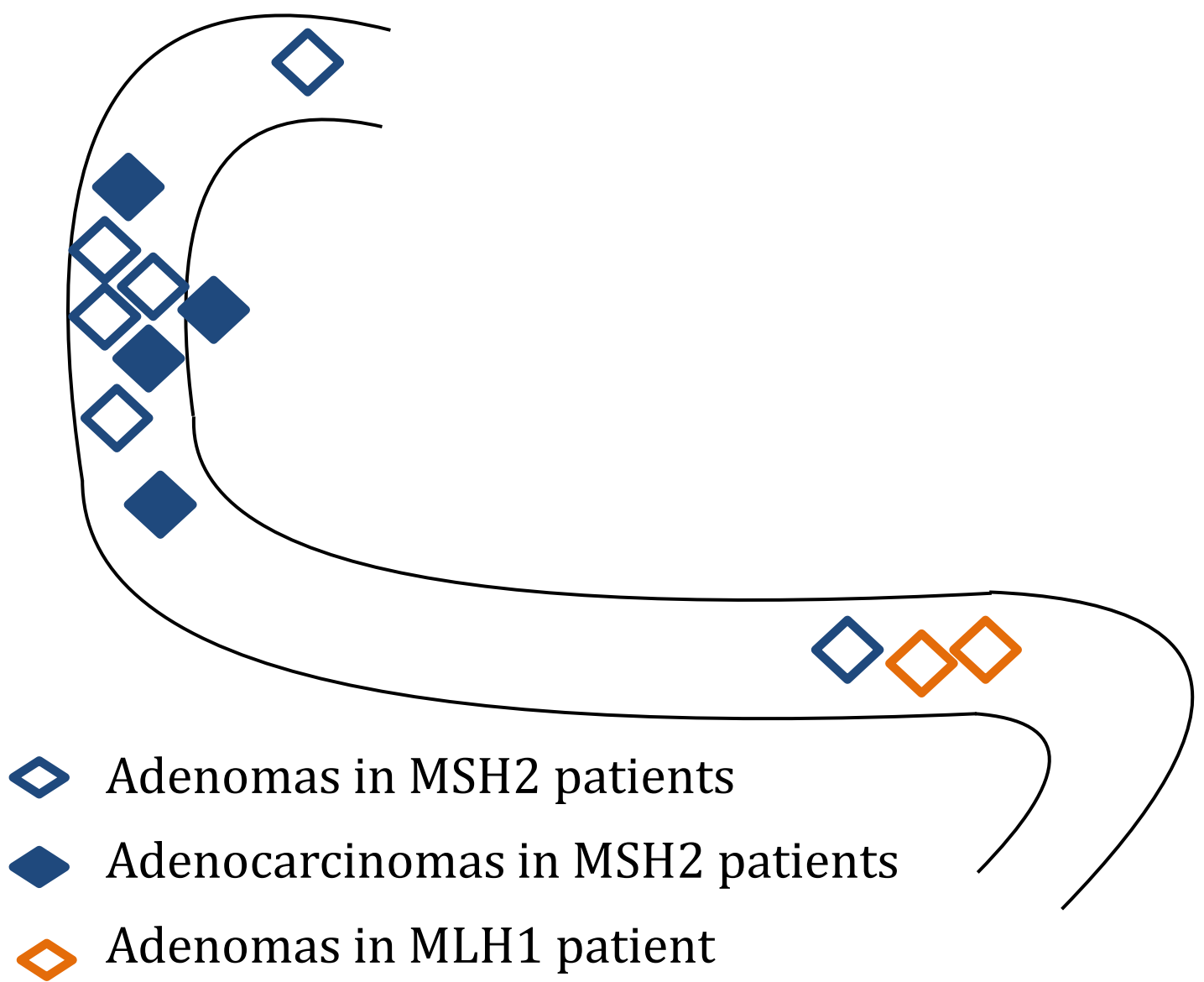




\begin{tabular}{|c|c|c|c|c|c|c|c|c|}
\hline $\begin{array}{l}\text { Patient } \\
\text { number }\end{array}$ & Gender & $\begin{array}{l}\text { Gene with } \\
\text { pathogenic }\end{array}$ & Smoker & $\begin{array}{l}\text { BMI } \\
\left(\mathrm{kg} / \mathrm{m}^{2}\right)\end{array}$ & $\begin{array}{l}\text { Age at } \\
\text { first } \\
\text { duodenal } \\
\text { lesion } \\
\text { diagnosis } \\
\text { (years) }\end{array}$ & $\begin{array}{l}\text { Familial } \\
\text { history } \\
\text { of } \\
\text { duodenal } \\
\text { lesion }\end{array}$ & $\begin{array}{l}\text { Personal } \\
\text { history of } \\
\text { digestive cancer } \\
\text { related to LS } \\
\text { (age of } \\
\text { diagnosis) }\end{array}$ & $\begin{array}{l}\text { Personal } \\
\text { history of } \\
\text { other LS or } \\
\text { possible LS } \\
\text { cancer (age of } \\
\text { diagnosis) }\end{array}$ \\
\hline 1 & Male & MSH2 & No & 26.9 & 71 & Yes & No & No \\
\hline 2 & Male & MSH2 & Yes & 30.1 & 49 & Yes & No & No \\
\hline 3 & Male & MSH2 & No & 24.9 & 51 & No & $\begin{array}{l}2 \text { synchronous } \\
\text { colorectal } \\
\text { adenocarcinomas } \\
(56-56)\end{array}$ & $\begin{array}{l}\text { Prostatic } \\
\text { adenocarcinoma } \\
\text { (58) }\end{array}$ \\
\hline 4 & Female & MSH2 & No & 23.3 & 53 & No & No & No \\
\hline 5 & Male & MSH2 & Former & 27.6 & 71 & No & $\begin{array}{l}\text { Gastric } \\
\text { adenocarcinoma } \\
\text { (71) }\end{array}$ & $\begin{array}{l}\text { Muir Torre } \\
\text { syndrom; } 3 \\
\text { Urothelial } \\
\text { Carcinomas (60- } \\
61-72) ; \\
\text { Prostatic } \\
\text { adenocarcinoma } \\
\text { (63) }\end{array}$ \\
\hline 6 & Male & MLH1 & No & 24.6 & 58 & No & $\begin{array}{l}2 \text { synchronous } \\
\text { colorectal } \\
\text { adenocarcinomas } \\
(53-53)\end{array}$ & $\begin{array}{l}\text { Sarcomatoid } \\
\text { carcinoma of } \\
\text { the adrenal } \\
\text { gland }(50)\end{array}$ \\
\hline 7 & Male & MSH2 & No & 28.7 & 54 & No & $\begin{array}{l}\text { Colorectal } \\
\text { adenocarcinoma } \\
\text { (43) }\end{array}$ & $\begin{array}{l}\text { Muir Torre } \\
\text { syndrom }\end{array}$ \\
\hline
\end{tabular}




\begin{tabular}{|c|c|c|c|c|c|c|c|}
\hline $\begin{array}{l}\text { Patient } \\
\text { Number }\end{array}$ & $\begin{array}{l}\text { Gene } \\
\text { Mutated }\end{array}$ & $\begin{array}{l}\text { Number of } \\
\text { duodenal } \\
\text { lesions } \\
\text { diagnosed }\end{array}$ & Location & $\begin{array}{l}\text { Histology of duodenal } \\
\text { lesions } \\
\left(n^{\circ} 1 / n^{\circ} 2 / N^{\circ} 3\right)\end{array}$ & $\begin{array}{l}\text { Lesion } \\
\text { Size }(\mathrm{mm})\end{array}$ & Paris Classification & $\begin{array}{l}\text { Immuno } \\
\text { Histochemistry* }\end{array}$ \\
\hline 1 & MSH2 & 2 & $\begin{array}{l}\text { Second } \\
\text { duodenum }\end{array}$ & LGD / HGD & $10 / 8$ & IIa / IIa & Loss of MSH2/MSH6 \\
\hline 2 & MSH2 & 3 & $\begin{array}{l}\text { Second } \\
\text { duodenum }\end{array}$ & $\begin{array}{l}\text { HGD / HGD / invasive } \\
\text { ADK }\end{array}$ & $20 / 50 / 50$ & IIa / IIa / IIa+c & Loss of MSH2/MSH6 \\
\hline 3 & MSH2 & 1 & Vater ampulla & Invasive ADK & 70 & III & Loss of MSH2/MSH6 \\
\hline$\overline{4}$ & MSH2 & 1 & Duodenal bulb & HGD & 70 & IIa & Loss of MSH2/MSH6 \\
\hline 5 & MSH2 & 2 & Genu inferius & $\begin{array}{l}\text { Intramucosal ADK / } \\
\text { HGD }\end{array}$ & $25 / 20$ & Is / IIa & Loss of MSH2/MSH6 \\
\hline$\overline{6}$ & MLH1 & 2 & $\begin{array}{l}\text { Fourth } \\
\text { duodenum }\end{array}$ & HGD / LGD & $25 / 12$ & IIa / IIa & Loss of MLH1/PMS2 \\
\hline 7 & MSH2 & 1 & $\begin{array}{l}\text { Second } \\
\text { duodenum }\end{array}$ & Invasive ADK & 55 & III & Loss of MSH2/MSH6 \\
\hline
\end{tabular}

